\title{
Formulation of Moringa oleifera Lam. based Bio-fortified Food Supplement for Pregnant Women in Madagascar, Indian Ocean
}

\author{
Randrantoarimbola Lazaniriana ${ }^{1}$, Rafalimanantsoa Jules ${ }^{1}$, Ratiarimananjatovo Narindra ${ }^{1}$, \\ Randriamanantena A. Andrin'iranto ${ }^{1}$, Ngiala Bongo ${ }^{2,3}$, Koto-te-Nyiwa Ngbolua ${ }^{2,3}$, \\ $\underline{\text { Robijaona Baholy }}^{1}$ \\ ${ }^{1}$ Engineering of Industrial, Agricultural and Food Processes and Systems, Polytechnic High School of \\ Antananarivo, University of Antananarivo, P.O. Box. 1500, 101 Antananarivo, Madagascar \\ ${ }^{2}$ Department of Biology, Faculty of Sciences, University of Kinshasa, P.O. Box. 190, Kinshasa XI, \\ Democratic Republic of the Congo \\ ${ }^{3}$ University of Gbado-Lite, P.O. Box 111 Gbado-Lite, Province of Nord-Ubangi, Democratic Republic \\ of the Congo \\ E-mail: holyrobi@gmail.com
}

\begin{abstract}
:
The pregnant woman feeding is very important for the optimal embryonic development of the zygote. The present study suggests a formulation of food supplement in soup form. We were able to make a soup which is composed of vegetables and animal products. This product like food supplement can cover the pregnancy nutrients needs. In fact, the nutrients deficiencies during the first 1000 days lead to chronic malnutrition. Hence, preventive actions concerning this nutritional plague are necessary. Among that, the food supplement for pregnant manufacture can compensate the micronutrients and protein-energy deficiencies. This animal and plantbased food supplement contains various minerals such as Mg (368 mg/100g DM); Ca (2003 $\mathrm{mg} / 100 \mathrm{~g}$ DM); K (1324 mg/100g DM); P (204 mg/100g DM); Cu (0, $57 \mathrm{mg} / 100 \mathrm{~g} \mathrm{DM}) ; \mathrm{Fe}$ $(28,2 \mathrm{mg} / 100 \mathrm{~g} D M)$. Besides, the product is composed by carbohydrates $(38,2 \mathrm{~g} / 100 \mathrm{~g} \mathrm{DM})$, fats $(2,3 \mathrm{~g} / 100 \mathrm{~g} D M)$, and proteins $(27,1 \mathrm{~g} / 100 \mathrm{~g} D M)$ fibers $(19,3 \mathrm{~g} / 100 \mathrm{~g} D M)$. It energetic value is $205 \mathrm{kCal}$ per $100 \mathrm{~g}$.
\end{abstract}

Keywords:

food supplement; Moringa oleifera; pregnancy; chronic malnutrition; micronutrients

\section{Introduction}

The child, during its first 1,000 days, is at the centre of concerns in the fight against all forms of malnutrition (Martorell, 2017). The quality of tomorrow's human capital will depend on the effectiveness of care during this period. The mother, in her role as nurturer and protector, is also the target of interventions. The mother's good nutrition is reflected in that of her child. In this case, women's nutrition during pregnancy is essential, since it conditions the growth of the foetus and the infant, and the smooth running of the pregnancy (WFP, 2015).

Pregnancy is a nutritionally demanding physiological condition. Three conditions appear to be necessary for the proper development of this stage: a mother who is well nourished to provide for her fetus, for her own needs and to prepare her body for breastfeeding; an efficient transmission of nutrients between mother and fetus; and a fetus that is able to use the nutrients received (Kominiarek, 2016; Koletzko et al., 2019). Every pregnant woman should consume foods from all food groups daily and at every meal to provide the body with all the nutrients it needs. No single food is complete. Only a combination of foods from different groups can ensure an optimal dietary balance (Skerrett \& Willett, 2012). 
According to a laboratory study conducted in various countries, pregnant women who eat poorly can promote the development of type 2 diabetes in their children (Guendouze, 2005; HKI, 2002). As such, the diet of pregnant women is of great importance in preventing chronic malnutrition in our future generations. This study aims to improve dietary supplements with a new formulation specifically designed for pregnant women.

\section{Research Methods}

\subsection{Raw Materials}

\section{a. Broccoli (Brassica oleracea L.)}

Broccoli provides nutrients that prevent the problem of constipation. The presence of fibre, fatty acids and vitamins regulates blood pressure and lowers bad cholesterol. Broccoli can protect blood vessels from damage and regulate blood pressure which can prevent heart attacks and strokes. It contains iron and folic acid, which help prevent anemia (Latté et al., 2011; Vasanthi et al., 2009). Broccoli allows cell multiplication, the constitution of the nervous system and the spinal cord of the fetus in the first trimester, because of the vitamin B 9 present in broccoli. Broccoli is considered to be one of the foods that provide the most vitamin C, which allows the absorption of iron (Gbolo et al., 2017; Mbemba, 2013).

\section{b. Spinach (Spinacia oleracea L.)}

Spinach is known to be a vegetable that aids digestion, which is why it is nicknamed "the broom of the stomach". It is one of the richest foods in protective antioxidants (vitamins A, C and E) that help our body fight excess free radicals, and one of the best anti-cancer plants because of its high antioxidant content and its massive and protective fiber content (Roberts \& Moreau, 2016). Spinach provides the body with a non-negligible magnesium intake, especially in women. It also has one of the highest levels of folic acid or vitamin B9, which is very useful for pregnant women in whom folate deficiency can cause spontaneous abortion or birth defects in the child. Iron helps with a normal appetite. It also helps transport oxygen through the body. This is important during pregnancy because of the extra blood supply needed to transport nutrients to your baby through the placenta (Mbemba, 2013; Shohag et al., 2011).

\section{c. Plantains (Musa paradisiaca L.)}

Its low glucose level helps to maintain gastrointestinal balance; plantain is a good remedy to stop chronic diarrhoea in children and infants. Plantain reduces the likelihood of getting an ulcer. It can play the role of a basic carbohydrate food in the diet, providing extra energy when needed (Alvarez-Acosta et al., 2009; Goel et al., 2001). Potassium is very important during pregnancy, and the plantain, which is very rich in it, is a good source. Folate is very important during pregnancy for the growth of new cells and genes (Mosso et al., 1990).

\section{d. Bean (Phaseolus vulgaris L.)}

Green beans contain an impressive amount of antioxidant pigments called flavonoids; these compounds synergistically slowed the growth of cancer cells. The soluble fiber contained in the beans is believed to help lower bad cholesterol levels. In addition, they have been proven to reduce inflammation and blood pressure, which is excellent for the heart. Vitamin $\mathrm{C}$ is a powerful antioxidant that contributes to the absorption of iron and is involved in the manufacture of collagen, a protein essential for the proper functioning of cartilage (Gbolo et al., 2017; Mbemba, 2013). 
The essential amino acids found in beans are very useful in pregnant women, especially in the second trimester, for the rapid growth of the fetus and to reduce the risk of fetal hypotrophy (Hayat et al., 2014).

\section{e. Moringa (Moringa oleifera Lam.)}

Moringa helps diabetic patients to control their blood sugar levels (Divi et al., 2012). It is recommended as a nutritional supplement because it helps digest food by providing minerals for efficient digestion (Upadhyay et al., 2015). This will help the body to absorb all the nutrients from food. It increases antioxidant levels; it contains about 46 antioxidants that help cells neutralize radicals. These antioxidants are also involved in preventing cell damage, the common pathway for cancer, aging, and a variety of diseases (Sreelatha et al., 2011; Suphachai, 2014). Moringa leaves have benefits on the following diseases: diabetes, cancer, gout, wounds, headaches, fever, sore throat, bronchitis, eye and ear infections, etc. (Sreelatha et al., 2011 ; Suphachai, 2014). Women who consumed Moringa leaves produced twice as milk as those who did not. Iron, necessary for fetal growth and placenta formation, is also present in these leaves (Asiedu-Gyekye et al., 2014; Ijarotin et al., 2013; TFL, 2005).

\section{The Tilapia (Oreochromis mossambicus Peters 1852: Cichlidae)}

Studies have shown a protective effect of fish consumption against cardiovascular disease. This effect is due to the presence of omega-3 fatty acids in fish flesh. Omega- 3 has anti-inflammatory properties. They act as precursors of chemical messengers that promote the proper functioning of the immune, circulatory and hormonal systems. They are essential for the development of the brain and the retina of the eye. Fish is a source of animal proteins, rich in phosphorus, and provides trace elements: zinc, copper, iodine, selenium and fluorine. It also contains vitamins A and D. During pregnancy, tilapia is an excellent source of nutrients for the mother or fetus in particular, in terms of protein-vitamins D and B 12 (EUFIC, 2009).

\section{f. The Eggshell}

Eggshells are the main waste product of egg breakers. It can be crushed and used as a calcium soil improver in the fields, thanks to its high calcium content. Eggshell is a source of calcium for pregnant women. It is also a source of minerals for the future skeleton of the embryo (QA, 1996).

\subsection{Preparation of Raw Materials}

\section{a. Case of Moringa}

1) Leaf stripping: Leaf stripping is the removal of leaflets from their petioles. At this stage, diseased or damaged leaves are removed.

2) Washing: The leaflets are washed in a tub with potable water to remove dust. The leaflets are then washed again with a $1 \%$ saline solution for 3 to 5 minutes to rid them of germs. Finally, they are washed again with clear water. They are then ready to be dried.

3) Solar drying: The leaflets are spread out on a van and exposed to the sun for 18 hours.

4) Crushing: The well-dried leaflets, which are dark in colour, are then crushed with a pestle mortar to make a powder.

There is also the pre-cooking method for broccoli, plantain, white beans, and tilapia.

\section{b. For Broccoli}

1) Washing: After harvesting, broccoli is washed using drinking water and bleach to purify it.

2) Preparation: The ends of the main stem are removed and bunch is cut off just below the crown. 
3) Pre-cooking: The basket is steamed in a pan filled with water a few inches from the bottom. The broccoli is placed in the steam basket and the lid is removed from the pan. The cooking time for the broccoli is 5 minutes.

\section{c. For the Plantains}

1) Peeling and preparation: Peel the green banana manually then cut them into slices about $1 \mathrm{~cm}$ thick.

2) Cooking: Put the peeled plantain in a saucepan with boiled water of $40^{\circ}$ and cook it until it is tender.

\section{d. For the White Bean}

1) Washing: Fresh beans are washed with clear water. Those that are deteriorated are then removed.

2) Preparation: The beans are cooked with drinking water for 25 minutes over low heat. After cooling them down, the seed coat of the beans is removed by hand.

\section{e. Treatment of Meat Product "Tilapia"}

1) Preparation: The fish is washed; its scales and viscera are removed. The fish are washed a second time.

2) Salting and cooking: The fish are sprinkled with salt. The fish are cooked over low heat in a pan for about 10 minutes. They are then dried in the open air under the sun for 18 hours to absorb moisture. Then they are crushed with a pestle mortar before being sieved.

\section{f. Treatment of Eggshells}

For eggshells, after washing, they are dried in the sun for 6 hours. Then the inner skin of the shells is peeled off. Then the shells are crushed with a mortar pestle. In order to make them digestible, a few drops of lemon juice are added to the shells to extract the calcium.

\subsection{Determination of the Biochemical Composition of the Soup}

The biochemical composition of the soup in organic macro-elements (carbohydrates, lipids, proteins) and minerals (Calcium, Magnesium, Phosphorus, Potassium) and microelements (Iron, Copper) was determined according to standard methods as previously described (Gbolo et al., 2017; Bukatuka et al., 2016; Mbemba, 2013).

\section{Discussion}

Table 1 gives the biochemical composition of the formulated soup.

Table 1. Soup biochemical composition

\begin{tabular}{|l|c|}
\hline Constituents & For $100 \mathrm{~g}$ of DS \\
\hline Moisture $(\%)$ & 7.5 \\
\hline Calories $(\mathrm{kCal})$ & 205 \\
\hline Proteins $(\mathrm{g})$ & 27.1 \\
\hline Lipids $(\mathrm{g})$ & 2.3 \\
\hline Glucids $(\mathrm{g})$ & 38.2 \\
\hline Fibres $(\mathrm{g})$ & 19.2 \\
\hline $\mathrm{Ca}(\mathrm{mg})$ & 2003 \\
\hline $\mathrm{Mg}(\mathrm{mg})$ & 368 \\
\hline $\mathrm{P}(\mathrm{mg})$ & 204 \\
\hline
\end{tabular}




\begin{tabular}{|l|c|}
\hline $\mathrm{K}(\mathrm{mg})$ & 1324 \\
\hline $\mathrm{Cu}(\mathrm{mg})$ & 0.57 \\
\hline $\mathrm{Fe}(\mathrm{mg})$ & 28.2 \\
\hline
\end{tabular}

From this table it appears that our food supplement contains $\mathrm{Mg}, \mathrm{Ca}, \mathrm{K}, \mathrm{P}, \mathrm{Cu}, \mathrm{Fe}$. It is well established that mineral elements form complexes with organic molecules in the organism, thus playing a role in different biological activities such as supporting and resisting the skeleton, stimulating various vital processes and osmosis, and participating in the balance and ion exchange between biological fluids and cells (Mbemba, 2013).

Micronutrients, iron (Fe), zinc ( $\mathrm{Zn})$, selenium (Se), iodine (I), carotenoids, and folates are essential nutrients required for human growth and development, as these contribute to various metabolic functions in human Warkentin \& Jha, 2019).

Micronutrient deficiencies afflict more than two billion individuals, or one in three people, globally. Such deficiencies occur when intake and absorption of vitamins and minerals are too low to sustain good health and development (Bouis \& Saltzman, 2017). These deficiencies may lead to serious illnesses such as poor growth, intellectual impairments, perinatal complications, and increased risk of morbidity and mortality. Further, they aggravate infectious and chronic diseases including osteoporosis osteomalacia, thyroid deficiency, colorectal cancer, and cardiovascular diseases and thus greatly impact quality of life (Warkentin \& Jha, 2019). Micronutrient malnutrition has received increased attention in recent decades at a global level and efforts have been made to combat them by various strategies such as increased food production, supplementation, food fortification, and biofortification (Warkentin \& Jha, 2019). The raw materials used are available to most households in Madagascar. The table also indicates that soup has a high nutritional value. The calcium content is considerable. The latter contributes to the mineralization of the foetal skeleton. Indeed, during pregnancy, there is an increase in intestinal calcium absorption (AVF, 2010; Manzanza, 2008).

The iron intake of the soup is quite important. Iron is a hematopoietic factor and its deficiency causes maternal fatigue and susceptibility to infections. The quantity of protein is also appreciable. It already constitutes almost half of the daily needs of pregnant women (AVF, 2010; Asiedu, 1991). The fortification of the present food supplement with the leaves of M. oleifera, a plant rich in chemical constituents of strong nutritional interest, notably vitamins ( $\mathrm{B}$ and $\mathrm{C}, \boldsymbol{\alpha}$-tocopherol), essential amino acids, Iron, Calcium, Phosphorus and Copper as well as nitrates and sulphur compounds, constitutes a better strategy for the management of pregnant women in Madagascar (Randrantoarimbola et al., 2018). It is very essential in the forthcoming days to increase the production of micronutrient-rich foods and improving dietary diversity that could substantially reduce micronutrient deficiencies. In the near term, consuming biofortified crops can help address micronutrient deficiencies by increasing the daily adequacy of micronutrient intakes among individuals throughout the lifecycle (Bouis \& Saltzman, 2017).

The formulation of Moringa oleifera Lam. based bio-fortified food supplement is good approach to combat malnutrition in both pregnant women and children in developing countries like Democratic Republic of the Congo (DRC), particularly in Gbado-Lite city (Province of Nord-Ubangi). This part of DRC belongs to the Ubangi eco-region, a subgroup of Northeastern Congolian lowland forests. This eco-region is one of the 200 globally priority terrestrial eco-regions known as the "G200" (Ngbolua et al., 2020a, b, Ngbolua et al., 2019a, b, c; Gbolo et al., 2019). 


\section{Conclusion}

Since malnutrition is a manifestation of multisectoral problems at all levels of society (family, community, region, and nation), nutritional considerations should be an integral part of all development programmes. With this in mind, our investigation decided to conduct a study on the possibility of producing soup, which is a dietary supplement for pregnant women rich in protein and micronutrients. The food supplement concocted shows us an interesting content of micronutrients and proteins per $100 \mathrm{~g}$ of DM.

\section{Acknowledgements}

The authors are indebted to the Office Nationale de la Nutrition, the Centre National de Recherche sur l'Environnement (Madagascar) and the University of Gbadolite (Democratic Republic of Congo) for their technical assistance.

\section{References}

Alvarez-Acosta, T., Leon, C., Acasta-Gonzolez, V., Porro-Soto, H., Cluet-Rodriguez, I. et al. (2009). Beneficial role of green plantain (Musa paradisiaca) in the management of persistent diarrhea: a prospective randomized trial. J. Am. Coll. Nutr., 28(2), 169-76.

Asiedu, J.J. (1991). La transformation des produits agricoles en zone tropicale - Approche technologique - Le soja. Edition Karthala et CTA, Pays-Bas. ISBN 2-86537-334-7.

Asiedu-Gyekye, I.J., Frimpong, M., Awortwe, C., Antwi, D.A., Nyarko, A.K. (2014). Microand Macro-elemental composition and safety evaluation of the nutraceutical Moringa oleifera leaves. J. Toxicol. 2014, 1-13. http://dx.doi.org/10.1155/2014/786979.

Association Végétarienne de France (AVF, 2010). Pourquoi et comment végétaliser notre alimentation? http://www.viande.info/fichiers/pdf/brochure-viande-info.pdf.

Bouis, H.E., Saltzman, A. (2017). Improving nutrition through biofortification: A review of evidence from HarvestPlus, 2003 through 2016. Global Food Security, 12, 49-58. doi: 10.1016/j.gfs.2017.01.009.

Bukatuka, F.C., Ngombe, K.N., Mutwale, K.P., Moni, B.M., Makengo, K.G., Pambu, L. A., Bongo, N.G., Mbombo, M.P., Musuyu, M.D., Maloueki, U., Ngbolua, K.N., Mbemba F.T. (2016). Bioactivity and nutritional values of some Dioscorea species traditionally used as medicinal foods in Bandundu, DR Congo. European Journal of Medicinal Plants, 14 (1), 1-11.

Divi, S.M., Bellamkonda, R., Dasireddy, S.K. (2012). Evaluation of antidiabetic and antihyperlipedemic potential of aqueous extract of Moringa oleifera in fructose fed insulin resistant and STZ induced diabetic Wistar rats: A comparative study, Asian J. Pharm. Clin. Res., 5, 67-72.

Éditions Québec Amérique (QA, 1996). Encyclopédie visuelle des aliments : Guide des substituts de la viande. http://www.lasanteaumenu.com/wpcontent/uploads/2011/03/Guide-des-substituts-de-viande.pdf.

European Food Information Council (Eufic, 2009). Les graisses saturées sous la loupe. http://www.eufic.org/article/fr/nutrition/graisses/artid/Graisses-saturees-loupe/.

Gbolo, B.Z., Asamboa, L.S., Bongo, G.N., Tshibangu, D.S.T., Kasali, F.M., Memvanga, P.B., Ngbolua, K.N., Mpiana, P.T. (2017). Bioactivity and Chemical Analysis of Drepanoalpha: An Anti-Sickle Cell Anemia Poly-Herbal Formula from CongoKinshasa. American J. Phytomedicine \& Clinical Therapeutics, 5:1.

Gbolo, Z.B., Ngbolua, K.N., Mpiana, P.T., Ndanga, B.A., Pangodi, A.J.M., Masengo, A.C., Mudogo, V. (2019). Evaluation of the Clinical Efficiency of an Antisickling Polyherbal Formula Drepanoalpha in a Sickle cell disease Patient in Gbado-Lite City (Democratic 
Republic of the Congo) by Quantum Magnetic Resonance Analyzer. Britain International of Exact Sciences (BIoEx) Journal, 1(1), 36-48.

Goel, R.K., Sairam, K., Rao, C.V. (2001). Role of gastric antioxidant and anti-Helicobacter pylori activities in antiulcerogenic activity of plantain banana (Musa sapientam var, paradisiaca). Indian J. Exp. Biol., 39(7), 719-722.

Guendouze, M. (2005). Diabète Gestationnel. www.solimed.net.

Hayat, I., Ahmad, A., Masud, T., Ahmed, A., Bashir, S. (2014). Nutritional and health perspectives of beans (Phaseolus vulgaris L.): an overiew. Crit. Rev. Food Sci. Nutr., 54(5), 580-92.

Helen Keller International (HKI, 2002). Module de nutrition pour les élèves de l'Institut de Santé Publique, Ministère de la santé publique et de lutte contre les endémies, République du Niger. www.hki.org.

Ijarotin, O.S., Adeoti, O.A., Ariyo, O. (2013). Comparative study on nutrient composition phytochemical and functional characteristics of raw, germinated, and fermented Moringa oleifera seed flour. Food Sci. Nutr., 1(6), 452-463.

Koletzko, B., Godfrey, K.M., Poston, L., Szajewska, H., Goudoever, J.B.V., Marita, D.W., Brands, B., Grivell, R.M., Deussen, A.R., Dodd, J.M., Patro-Golab, B., Zalewski, B.M. (2019). Nutrition during pregnancy, lactation and early childhood and its implications for maternal and long-term child health: the early nutrition projects recommendations. Annals of Nutrition and Metabolism, 74, 93-106.

Kominiarek, M. (2016). Nutrition Recommendations in Pregnancy and Lactation. Medical Clinics of North America, 100(6), 1199-1215.

Latté, K.P., Appel, K.E., Lampen, A. (2011). Health benefits and possible risks of broccoli: An overview. Food chem. Toxicol., 49(12), 3287-309.

Manzanza, K.G. (2008). Connaissance des gestantes sur les mesures d'hygiène pendant la grossesse. Travail de fin de cycle, Département des Sciences de la Santé, Faculté des Sciences, Université Pédagogique Nationale, République démocratique du Congo. www.memoireonline.com.

Martorell, R. (2017). Improved Nutrition in the first 1000 days and adult human capital and health. American Journal of Human Biology, 29(2):1-24. doi:10.1002/ajhb.22952.

Mbemba, F. (2013). Aliments et denrées alimentaires traditionnels du Bandundu en RD Congo : Répertoire et composition en nutriments, Ed. Le Harmattan, Paris, 322p.

Mosso, K., Lingani, M., Angbo, S. (1990). Mise au point de la farine protéinée de banane plantain. Application : Fabrication de biscuits secs. Industries Alimentaires et Agricoles, 107(3), 135-138.

Ngbolua, K.N., Kumbali, N.G., Mbembo-wa-Mbembo, B., Kohowe, P.S., Kogana, K.F., Bongo, N.G., Masengo, A.C., Djolu, D.R. (2020a). First Report on Three Cases of Monkey pox in Nord Ubangi Province (Democratic Republic of the Congo). Britain International of Exact Sciences (BIoEx) Journal, 2(1), 120-125.

Ngbolua, K.N., Ngemale, G.M., Masengo, A.C., Ndolete, G.J.P., Bongo, N.G., Ndanga, B.A., Tshibangu, D.S.T., Tshilanda, D.D. (2020b). Survey on the Sale of Megaphrynium Macrostachyum (Marantaceae) Leaves in Gbado-Lite City and Surroundings (Nord Ubangi Province, Democratic Republic of the Congo). Budapest International Research in Exact Sciences (BirEx) Journal, 2(2), 157-167.

Ngbolua, K.N., Zuangbo, I., Molongo M., Masengo, A.C., Djolu, D.R., Yabuda, H., Bongo, N.G., Gbolo, Z.B., Monde-te-Kazangba, G. (2019a). Effect of Agricultural Residues Based-Compost on the Yield of Amaranthus hybridus L. (Amaranthaceae) in GbadoLite City, Nord-Ubangi (Democratic Republic of the Congo). Budapest International Research in Exact Sciences (BirEx) Journal, 1(4), 53-61.

Ngunde-te-Ngunde, S., Lengbiye, M.E., Tshidibi, D.J., Kengo, V.F., Djolu, D.J., Masengo, A.C., Gbolo, Z.B., Iteku, B.J., Mpiana, P.T., Ngbolua, K.N. (2019b). Antisickling and 
Antibacterial Activites of Anthocleista schweinfurthii Gilg. (Gentianaceae) from Nonhuman Primates Pharmacopoeia in Democratic Republic of the Congo. Budapest International Research in Exact Sciences, 1(3), 14-20, 2019.

Ngbolua, K.N., Kumbali N.G., Mbembo-wa-Mbembo, B., Djolu D.R., Bongo, N.G., Falanga, M.C., Gbolo, Z.B., Masengo, A.C., Libwa, M.T.B. (2019c). Epidemio-therapeutic Survey on Malnourished Children Aged 0-5 Years Old in the Gbado-Lite Health Zone (Nord Ubangi Province, Democratic Republic of the Congo). Britain International of Exact Sciences (BIoEx) Journal, 1(1), 22-28.

Randrantoarimbola, L., Rafalimanantsoa, J., Ratiarimananjatovo, N., Randriamanantena, A.A., Rakotondrazafy, J.I.N., Ngbolua, K.N., Robijaona, B. (2018). Valorization of local products to fight against chronic malnutrition in Malagasy rural households using Food supplements bio-fortified by the leaves powder of Moringa oleifera Lam. J. of Adv. Med. \& Life Sci., 6(4), 1-4. doi: 10.5281/zenodo.1303307.

Roberts, J.L., Moreau, R. (2016), Functional properties of spinach (Spinacia oleracea L.) phytochemicals and bioactives. Food Funct., 7(8), 3337-53.

Shohag, M.J.I., Yan-Yan, W., Ning, Y., Jie, Z., Kaiwang et al. (2011). Natural variation of folate content and composition in spinach (Spinacia oleracea) Germplasm. J. Agric. Food Chem., 59(23), 12520-12526.

Skerrett, P.J., Willett, W.C. (2012). Essentials of healthy eating: A guide. Journal of Midwifery Womens Health, 55(6), 492-501.

Sreelatha, S., Jeyachitra, A., Padma, P.R. (2011). Antiproliferation and induction of apoptosis by Moringa oleifera leaf extract on human cancer cells. Food Chem. Toxicol., 49, $1270-1275$.

Suphachai, C. (2014). Antioxidant and anticancer activities of Moringa oleifera leaves. J. Med. Plants Res., 8(7), 318-325.

Tree for Life (TFL) Moringa book (2005). http://www.treeforlife.org.

Upadhyay, P., Yadar, M.K., Mishra, S., Sharma, P., Purohit, S. (2015). Moringa oleifera: A review of the medical evidence for its nutritional and pharmacological properties. Int. J. Res. Pharm. Sci., 5(2), 12-16.

Vasanthi, H.R., Mukherjee, S., Daw, D.K. (2009). Potential health benefits of broccoli: A chemico-biological overview. Mini Rev. Med. Chem., 9(6), 749-59.

Warkentin, T.D., Jha, A.B. (2019). Biofortification of pulse crops: status and future perspectives. Plants, 9(73), 1-24.

World Food Programme (WFP, 2015). Analyse globale de la Sécurité Alimentaire, de la Nutrition et de la Vulnérabilité (CFSVA+N), Madagascar 2010. www.wfp.org. 